\title{
Serological evidence of Toxoplasma gondii occurrence in naturally infected sheep in the Teresina microregion, Piauí, Brazil
}

\author{
Lauro César Soares Feitosa1,* (1) https://orcid.org/0000-0001-9675-3872 \\ Andressa de Carvalho Teixeira Lima Celestino' (10) https://orcid.org/0000-0003-1249-5453 \\ Siluana Benvindo Ferreira' (1) https://orcid.org/0000-0001-6664-8131 \\ Janaina de Fátima Saraiva Cardoso' (1) https://orcid.org/0000-0002-4484-4403 \\ Taciana Galba da Silva Tenório' (10) https://orcid.org/0000-0001-9376-2079 \\ Ney Rômulo de Oliveira Paula' (10) https://orcid.org/0000-0002-0484-3748 \\ Ana Lys Bezerra Barradas Mineiro' 1 i] https://orcid.org/0000-0002-3997-1694 \\ 1. Universidade Federal do Piauí - Centro de Ciências Agrárias - Departamento de Clínica e Cirurgia Veterinária - Teresina (PI), \\ Brazil. \\ ${ }^{*}$ Corresponding author: Icsfeitosa17@outlook.com
}

\begin{abstract}
Toxoplasmosis is a zoonosis of reproductive nature that is transmitted to humans mainly by ingestion of undercooked meat or drinking oocyte-contaminated water. The slaughter of small ruminants in clandestine slaughterhouses and the presence of companion animals in these locations may be epidemiologically important for the dissemination of the disease. The objective of the present study was to determine toxoplasmosis prevalence by researching anti- Toxoplasma gondii antibodies in meat sheep herds from farms in Teresina microregion, Piauí, Brazil. A total of 450 blood samples were collected from sheep of both sexes, belonging to 28 herds from the 14 municipalities that comprise the microregion. The samples were analyzed by the enzyme-linked immunosorbent assay (ELISA), and the presence of anti-T. gondii antibodies was observed in 62\% (279/450) of the animals in all the municipalities and on at least one farm in each municipality. The high occurrence of positive animals is an indication of reproductive problems in these herds, characterizing a problem for both sheep rearing and public health.
\end{abstract}

Keywords: zoonosis; miscarriage; small ruminant.

\section{INTRODUCTION}

In Brazil, the state of Piauí has the third largest goat herd (1.8 million) and the fifth largest sheep herd (1.6 million), which represents about $17.16 \%$ and $8.63 \%$ of the national herd, respectively (IBGE, 2019). In spite of the evolution during the last decade, sheep and goat rearing is still negatively influenced by factors including inappropriate health management. Several infectious diseases are still highly prevalent in sheep and goats, especially in the Brazilian Northeast (MESQUITA et al., 2019; RÊGO et al., 2016). Toxoplasmosis is among the main diseases that cause miscarriage in sheep and goats.

Toxoplasmosis is a widely distributed zoonosis that affects humans and warm-blooded animals, caused by the protozoan Toxoplasma gondii (AMENDOEIRA et al., 1999). The agent belongs to the filo Apicomplexa, family Sarcocystidae, subfamily Toxoplasmatinae, genus Toxoplasma (FIALHO et al., 2009; GJERDE, 2013). Its life cycle is heteroxenous and all warm-blooded animals (mammals and birds) can take part in the cycle as intermediary hosts, but felines are the definitive hosts (AMARANTE, 2014).

The disease is characterized by a reproductive infectious infirmity that causes serious losses to sheep rearing. Pregnant females infected by T. gondii can present embryonic death and reabsorption, fetal death, fetal mummification,

Received: Apr 18, 2020. Accepted: Oct 22, 2021

Associate Editor: Silvia Galleti

Peer Review History: Double-blind Peer Review. 
miscarriage and perinatal death (DUBEY, 2010). Miscarriage usually occurs during the last four weeks of pregnancy, and its occurrence can affect up to $58.3 \%$ pregnant ewes, that causes an important economic loss to the affected farms (MOTTA et al., 2008).

Serological diagnosis of toxoplasmosis is based on the identification of specific anti- $T$. gondii antibodies. Various serological tests have been used, including hemagglutination (HAI), indirect immunofluorescence reaction (RIFI), modified agglutination test (MAT), agglutination by immunoadsorption (ISAGA) and immune-enzymatic test (ELISA). However, the ELISA, MAT and RIFI tests are the currently preferred methods to diagnose infection by T. gondii in sheep, because they ensure good specificity and sensitivity (AMARANTE; 2014).

The importance of T. gondii for small ruminant reproduction is well-known. On analyzing goat products suspected of infection by T. gondii in southern Brazil, PESCADOR et al. (2007) reported the link between reproductive losses and infection, showing the presence of both macro- and microscopic lesions (lymphoplasmacytic infiltrates in the brain and lungs, interstitial lymphoplasmacytic nephritis, necrotic lymphadenitis and periportal lymphoplasmacytic hepatitis). Considering the relevance of the problems brought on by infection by T. gondii, both for public health and for the sheep and goat rearing reproductive sector, the objective of the present study was to determine its prevalence in meat sheep herds on farms in the Teresina microregion, Piauí, Brazil.

\section{MATERIAL AND METHODS}

The experimental protocol was approved by the ethics committed in animal experimentation at the Federal University of Piauí, Brazil (CONCEA-UFPI), protocol number 020/13. The research was carried in the Teresina microregion, situated in the central-north mesoregion of the state of Piauí, consisting of 14 municipalities (Altos, Beneditinos, Coivaras, Curralinhos, Demerval Lobão, José de Freitas, Lagoa Alegre, Lagoa do Piauí, Miguel Leão, Monsenhor Gil, Nazária, Pau D’Arco do Piauí, Teresina and União (Fig. 1).
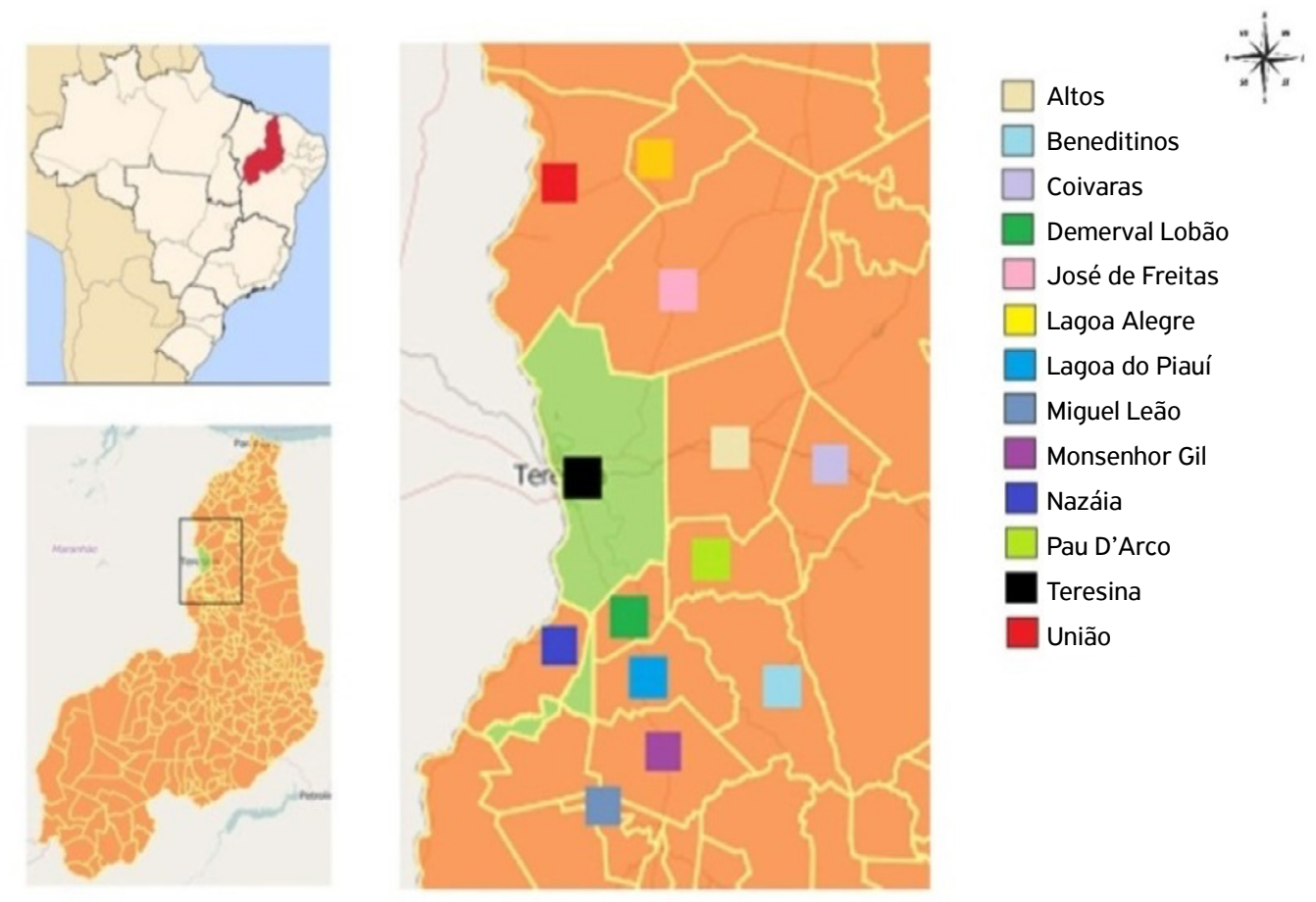

Figure 1. Map characterizing the homogeneous microregion of Teresina, Piauí, Brazil. Source: Retrieved from REBELO et al. (2020).

Twenty-eight herds were randomly selected from all the 14 municipalities, and animals of both sexes were chosen over 6 months. The number of farms and animals chosen in the municipalities and in each herd was statistically preestablished according to THRUSFIELD (2004) and based on farm and herd registration records of the Piauí Agricultural Defense Agency. The sampling process involved 20 randomly chosen animals per farm, consisting of $60 \%$ lambing ewes, $30 \%$ young 
sheep (between 6 and 12 months) and 10\% adult reproducers rams. In addition to the animal's sex, the rearing system was also analyzed, and divided as intensive, semi-intensive and extensive.

A total of 450 blood samples were collected, after cleaning the region with $2 \%$ iodine alcohol, by jugular vein puncture using a vacuum system and tubes without anticoagulant. The tubes were identified with data for the municipality, farm and animal sex and number. After collection, the samples were kept at $-20^{\circ} \mathrm{C}$ until processing. Later, they were centrifuged for $10 \mathrm{~min}$ at 2,500 rpm, the serum was placed in $1.5-\mathrm{mL}$ microtubes and the ELISA was applied.

The indirect ELISA tests were performed using a specific kit for in vitro diagnosis of sheep ovine toxoplasmosis (Imunoteste Toxoplasma, RIFI, Laboratório Imunodot Diagnósticos, Brazil), following the manufacturer's recommendations. The statistical analysis was carried out by the chi-squared test with estimated $5 \%$ error to assess the differences between the municipalities, sex and rearing systems.

\section{RESULTS AND DISCUSSION}

A general prevalence was found in $62 \%$ (279/450) of samples for anti-T. gondii antibodies. There was at least one seropositive animal in all the 14 municipalities in the Teresina microregion, and specific prevalence ranged from $33.3 \%$ to $70.0 \%$, but there was no significant difference between the municipalities $(\mathrm{p}>0.05)$ (Table 1$)$.

Table 1. Total number of samples, number of positive animals and prevalence of sheep seropositive for infection by $T$. gondii by the indirect ELISA test in the Teresina/PI microregion, Brazil.

\begin{tabular}{lccc}
\hline City & No. of samples & No. of positive animals & Prevalence (\%) \\
\hline Monsenhor Gil & 79 & 55 & 70.0 \\
\hline José de Freitas & 117 & 77 & 65.8 \\
\hline Pau D'Arco do Piauí & 14 & 09 & 64.3 \\
\hline Altos & 33 & 21 & 63.6 \\
\hline Beneditinos & 52 & 33 & 63.5 \\
\hline Demerval Lobão & 10 & 06 & 60.0 \\
\hline Coivaras & 33 & 19 & 57.6 \\
\hline Lagoa Alegre & 33 & 18 & 54.5 \\
\hline União & 48 & 26 & 54.2 \\
\hline Teresina & 15 & 08 & 53.3 \\
\hline Nazária & 04 & 02 & 50.0 \\
\hline Miguel Leão & 02 & 01 & 50.0 \\
\hline Lagoa do Piauí & 07 & 03 & 42.8 \\
\hline Curralinhos & 03 & 01 & 33.3
\end{tabular}

Source: Elaborated by the authors.

The prevalence found in the present study was higher than that reported in some parts of Brazil. There are reports of prevalence ranging from 9.5\% (Paraná) to 18.75\% (Maranhão), 35.3\%, and 16.9\% (Pernambuco) and 38.5\% (Espírito Santo) and up to $57.6 \%$ (Minas Gerais). Furthermore, it was higher than data reported for other microregions of Piauí such as the high-mid Gurguéia microregion (48.7\%). (BASSI et al., 2013; MORAES et al., 2011; PEREIRA et al., 2012; RÊGO et al., 2016; ROMANELLI et al., 2007; SILVA et al., 2003; TESOLINI et al., 2012). Similar to this study, PEREIRA et al. (2012) reported animals seropositive for T. gondii on $100 \%$ of the farms analyzed in the state of Pernambuco, Brazil. Lack of health control, precarious conditions on many farms and the different diagnostic techniques used may have determined these differences.

A $63.2 \%$ prevalence was observed in the females (261/413) and $48.6 \%$ in the males (18/37), and it was statistically higher in the females $(\mathrm{p}<0.05)$ (Table 2). Working with pregnant ewes, MOTTA et al. (2008) reported that 33.3\% (3/9) tested positive for anti-T. gondii antibodies and there was miscarriage in the last month of pregnancy in $58.3 \%$. In spite of 
this, SAKATA et al. (2012) did not report any significant differences in seroprevalence between the sexes of the affected animals, whereas SILVA et al. (2003) reported higher seroprevalence for T. gondii in rams than in ewes (50\% vs. 31.11\%). MORAES et al. (2010) reported the presence of T. gondii in the semen of naturally infected rams, showing the importance of the diagnosis in these individuals in the possible sexual transmission to pubescent females in the herd. In this sense, the form of data collection (privileging females) and especially the herd constitution (mostly females) may have been the determining factor in obtaining these results.

Table 2. Distribution of sheep seropositive for toxoplasmosis identified by the indirect ELISA test, in relation to sex and rearing system in the Teresina/PI microregion, Brazil.

\begin{tabular}{lccc}
\hline Sex & No of animals (\%) & Positive (\%) & Negatives (\%) \\
\hline Male & $37(8.2)$ & $18(48.6) \mathrm{a}$ & $19(51.4) \mathrm{a}$ \\
\hline Female & $413(91.8)$ & $261(63.2) \mathrm{b}^{*}$ & $152(36.8) \mathrm{a}$ \\
\hline Total & $\mathbf{4 5 0}$ & $\mathbf{2 7 9}$ & $\mathbf{1 7 1}$ \\
\hline Breeding system & $\mathbf{N}^{\circ}$ of animals (\%) & Positive (\%) & Negatives (\%) \\
\hline Intensive & $39(8.7)$ & $2(5.1) \mathrm{a}$ & $37(74.9) \mathrm{a}$ \\
\hline Semi-intensive & $114(25.3)$ & $27(23.7) \mathrm{a}$ & $87(76.3) \mathrm{a}$ \\
\hline Extensive & $297(66.0)$ & $250(84.2) \mathrm{b}^{*}$ & $47(15.8) \mathrm{a}$ \\
\hline Total & 450 & $\mathbf{2 7 9}$ & $\mathbf{1 7 1}$
\end{tabular}

* Significant statistical difference.

Source: Elaborated by the authors.

Regarding the rearing system, the intensive, semi-intensive and extensive systems showed a T. gondii prevalence of 5.1, 23.7 and $84.2 \%$, respectively, and significant difference was observed for the extensive system $(\mathrm{p}<0.05)$ (Table 2). This result is similar to that observed by LUCIANO et al. (2011) who reported higher seroprevalence of T. gondii in animals reared under the extensive system, compared to the intensive and semi-intensive systems. The difficulty in controlling environmental health for animals reared extensively, and pasture sharing with other species, especially felines, may explain the higher prevalence in this type of rearing system. Although it was not assessed in this study, cats may be present on these farms, sharing environments with the animals studied. Unlike the results of the present study, intensive rearing was considered one of the risk factors for toxoplasmosis in goats, but not in sheep (PEREIRA et al., 2012).

It was observed that in areas with a high concentration of sheep rearing, the type of rearing system has changed and the extensive system has given way to the implantation of the intensive rearing system, where infectious diseases are more easily disseminated by contact with other species and intense animal management. In this context, the study of toxoplasmosis among these animals is relevant, due to the potential occurrence of reproductive problems, considering the real possibility of congenital transmission and sheep losses (SILVA et al., 2006), that impact directly on production.

The main transmission means of T. gondii to man is by intake of meat, milk, water or fomites contaminated with oocytes or bradyzoites (SILVA et al., 2006). Considering that animals that are slaughtered clandestinely usually come from localities with inadequate health management, the possibility of these animals being carriers of several diseases, including toxoplasmosis, is increased. VIANA et al. (2014) reported that clandestine slaughter of small ruminants was, and still is, a reality in Teresina/PI, and showed that the precarious conditions of these clandestine slaughter locations, the environmental conditions, the professionals who perform the slaughter, and the presence of companion animals in these locations culminate in risk for several population groups.

\section{CONCLUSION}

Infection by T. gondii is highly prevalent in the sheep herds in the microregion of Teresina/PI, Brazil, especially in females extensively reared. Considering the importance and representativity of the species in the local and state economy, and the risk to public health, control and health education measures should be implemented with the farmers and professionals involved, along with the general population. 
AUTHORS' CONTRIBUTIONS

Conceptualization: Feitosa, L.C.S.; Writing-Review \& Editing: Ferreira, S.B.; Formal Analysis: Mineiro, A.L.B.B.; Resources: Tenório, T.G.S., Cardoso, J.F.S.; Supervision: Celestino, A.C.T.L., Paula, N.R.O.

AVAILABILITY OF DATA AND MATERIAL

Data will be available upon request

FUNDING

Not applicable.

\section{CONFLICTS OF INTEREST}

There are no conflicts of interest.

\section{ETHICAL APPROVAL}

The experimental protocol was approved by animal experimentation ethics committee of Universidade Federal do Piauí (AEEC -FUP) under protocol number 020/2013.

\section{ACKNOWLEDGEMENTS}

The authors would like thank the Universidade Federal do Piauí for the support.

\section{REFERENCES}

AMARANTE, A.F.T. do. Toxoplasmose, neosporose e sarcocistose. In: Os parasitas de ovinos. São Paulo: Editora UNESP, 2014. 153 p. Chap. 8. AMENDOEIRA, M.R.R.; COSTA, T.; SPALDING, S.M. Toxoplasma gondii Nicolle \& Manceaux, 1909 (Apicomplexa: Sarcocystidae) e a toxoplasmose. Revista Souza Marques, Rio de Janeiro, v.1, n.1, p.15-29, 1999.

BASSI, P.B.; BITTAR, J.F.F.; SILVA, C.C. da; SANTOS, J.P. dos; BITTAR, E.R. Prevalência de parasitos gastrintestinais e de toxoplasmose em ovinos da região de Uberaba, MG. Bioscience Journal, Uberlândia, v.29, n.2, p.434-438, 2013. Available from: http://www.seer.ufu.br/ index.php/biosciencejournal/article/view/14703. Access on: 21 Jan. 2020.

DUBEY, J.P. Toxoplasmosis in goats (Capra hircus). In: Toxoplasmosis of animals and humans. 2nd ed. Boca Raton: CRC Press, 2010. 137p. Chap. 5.

FIALHO, C.G.; TEIXEIRA, M.C.; ARAÚJO, F.A.P. de. Toxoplasmose animal no Brasil. Acta Scientiae Veterinariae, Porto Alegre, v.37, n.1, p.1-23, 2009. https://doi.org/10.22456/1679-9216.16180

GJERDE, B. Characterisation of full-length mitochondrial copies and partial nuclear copies (numts) of the cytochrome b and cytochrome c oxidase subunit I genes of Toxoplasma gondii, Neospora caninum, Hammondia heydorni and Hammondia triffittae (Apicomplexa: Sarcocystidae). Parasitology Research, Perth, v.112, n.4, p.1493-1511, 2013. https://doi.org/10.1007/s00436-013-3296-4

IBGE - Instituto Brasileiro de Geografia e Estatística. Pesquisa da Pecuária Municipal. Tabela 3939: efetivo dos rebanhos, por tipo de rebanho (2008 a 2018). Rio de Janeiro: IBGE, 2019. Available from: https://sidra.ibge.gov.br/tabela/3939. Access on: 2 Sept. 2019.

LUCIANO, D.M.; MENEZES, R.C.; FERREIRA, L.C.; NICOLAU, J.L.; NEVES, L.B. das; LUCIANO, R.M.; DAHROUG, M.A.A.; AMENDOEIRA, M.R.R. Soroepidemiologia da toxoplasmose em caprinos e ovinos de três municípios do estado do Rio de Janeiro. Pesquisa Veterinária Brasileira, Rio de Janeiro, v.31, n.7, p.569-574, 2011. https://doi.org/10.1590/S0100-736X2011000700004

MESQUITA, E.P.; OLIVEIRA, J.M.B.; SILVA, G.M.; TORRES, S.M.; OLIVEIRA, A.A.F.; SILVA JÚNIOR, V.A.; MOTA, R.A.; AMORIM, M.J.A.A.L. Imunodetecção de Toxoplasma gondii em tecido placentário de cabras naturalmente infectadas. Arquivo Brasileiro de Medicina Veterinária e Zootecnia, Belo Horizonte, v.71, n.1, p.86-92, 2019. https://doi.org/10.1590/1678-4162-9797

MORAES, E.P.B.X.; FARIA, E.B.; BATISTA, A.M.; FREITAS, A.C.; SILVA, J.C.R.; ALBUQUERQUE, P.P.F.; MOTA, R.A. Detecção de Toxoplasma gondii no sêmen de ovinos naturalmente infectados. Pesquisa Veterinária Brasileira, Rio de Janeiro, v.30, n.11, p.915-917, 2010. https://doi.org/10.1590/S0100-736X2010001100003 
MORAES, L.M. de B.; RAIMUNDO, J.M.; GUIMARÃES, A.; SANTOS, H.A.; MACEDO JUNIOR, G. de L.; MASSARD, C.L.; MACHADO, R.Z.; BALDANI, C.D. Occurrence of anti-Neospora caninum and anti-Toxoplasma gondii IgG antibodies in goats and sheep in western Maranhão, Brazil. Revista Brasileira de Parasitologia Veterinária, Jaboticabal, v.20, n.4, p.312-317, 2011. https://doi.org/10.1590/ S1984-29612011000400010

MOTTA, A.C.; VIEIRA, M.I.B.; BONDAN, C.; EDELWEISS, M.I.A.; DAMETTO, M.A.; GOMES, A. Aborto em ovinos associado à toxoplasmose: caracterização sorológica, anatomopatológica e imunoistoquímica. Revista Brasileira de Parasitologia Veterinária, Jaboticabal, v.17, p.204-208, 2008. Suppl. 1. Available from: http://www.rbpv.org.br/documentos/17supl.12008/Protozool003.pdf. Access on: 14 Feb. 2020.

PEREIRA, M. de F.; PEIXOTO, R. de M.; LANGONI, H.; GRECA JUNIOR, H.; AZEVEDO, S.S. de; PORTO, W.J.N.; MEDEIROS, E.S. de; MOTA, R.A. Fatores de risco associados à infecção por Toxoplasma gondii em ovinos e caprinos no estado de Pernambuco. Pesquisa Veterinária Brasileira, Rio de Janeiro, v.32, n.2, p.140-146, 2012. https://doi.org/10.1590/S0100-736X2012000200009

PESCADOR, C.A.; OLIVEIRA, E.C.; PEDROSO, P.M.O.; BANDARRA, P.M.; OKUDA, L.H.; CORBELLINI, L.G.; DRIEMEIER, D. Perdas reprodutivas associadas com infecção por Toxoplasma gondii em caprinos no sul do Brasil. Pesquisa Veterinária Brasileira, Rio de Janeiro, v.27, n.4, p.167-171, 2007. https://doi.org/10.1590/S0100-736X2007000400007

REBELO, P.R.V. et al. Prevalência e fatores de risco da Leucose Enzoótica Bovina em rebanhos bovinos da microregião de Teresina, Estado do Piauí, Brasil. Revista Agrária Acadêmica, Imperatriz, v.3, n.6, p.6-15, 2020. https://doi.org/10.32406/v3n62020/6-15/agrariacad

RÊGO, W.M.F. et al. Risk factors for Toxoplasma gondii infection in goats and sheep raised in the State of Piauí in northeast Brazil. Small Ruminant Research, Bet Dagan, v.141, p.17-23, 2016. https://doi.org/10.1016/j.smallrumres.2016.04.010

ROMANELLI, P.R.; FREIRE, R.L.; VIDOTTO, O.; MARANA, E.R.M.; OGAWA, L.; PAULA, V.S.O. de; GARCIA, J.L.; NAVARRO, I.T. Prevalence of Neospora caninum and Toxoplasma gondii in sheep and dogs from Guarapuava farms, Paraná State, Brazil. Research in Veterinary Science, Rome, v.82, n.2, p.202-207, 2007. https://doi.org/10.1016/j.rvsc.2006.04.001

SAKATA, F.B.L.S.; BELLATO, V.; SARTOR, A.A.; MOURA, A.B. de; SOUZA, A.P. de; FARIAS, J.A. Toxoplasma gondii antibodies sheep in Lages, Santa Catarina, Brazil, and comparison using IFA and ELISA. Revista Brasileira de Parasitologia Veterinária, Jaboticabal, v.21, n.3, p.196-200, 2012. https://doi.org/10.1590/S1984-29612012000300004

SILVA, A.V. da; CUNHA, E.L.P.; MEIRELES, L.R.; GOTTSCHALK, S.; MOTA, R.A.; LANGONI, H. Toxoplasmose em ovinos e caprinos: estudo soroepidemiológico em duas regiões do Estado de Pernambuco, Brasil. Ciência Rural, Santa Maria, v.33, n.1, p.115-119, 2003. https://doi.org/10.1590/S0103-84782003000100018

SILVA, K.L.M. de V.; LA RUE, M.L. de. Possibilidade da transmissão congênita de Toxoplasma gondii em ovinos através de seguimento sorológico no município de Rosário do Sul, RS, Brasil. Ciência Rural, Santa Maria, v.36, n.3, p.892-897, 2006. https://doi.org/10.1590/ S0103-84782006000300025

TESOLINI, P.M.A.; LEÃO, A.G.C. de; BELTRAME, M.A.V.; GUMIEIRO, M.V.; BARIONI, G. Soroprevalência de anticorpos anti-Toxoplasma gondii em ovinos da raça Santa Inês na região da Grande Vitória, estado do Espírito Santo. Revista Brasileira de Ciência Veterinária, Niterói, v.19, n.1, p.38-41, 2012. https://doi.org/10.4322/rbcv.2014.080

THRUSFIELD, M. Epidemiologia veterinária. 2nd. ed. São Paulo: Roca, 2004. 556p.

VIANA, F.J.C.; FRANKLIN, F.L.A.A.; PEREIRA, C.F. de C.; LIMA, D.B.C.; CONDE JUNIOR, A.M.; RIZZO, M.S. Abate clandestino de suínos e pequenos ruminantes na cidade de Teresina, Piauí: Implicações na saúde ocupacional. Revista Interdisciplinar de Ciência e Saúde, Teresina, v.1, n.1, p.38-47, 2014. Available from: https://revistas.ufpi.br/index.php/rics/article/view/2155. Access on: 19 June 2019. 